\title{
External Leveraging and Technological Upgrading Among East Asian Firms in the US
}

\author{
JINN-YUH HSU*, JESSIE P. POON** \& HENRY WAI-CHUNG YEUNG ${ }^{\dagger}$ \\ *Department of Geography, National Taiwan University, Taipei, Taiwan, **Department of Geography, \\ University at Buffalo-SUNY, Buffalo, NY, USA, ${ }^{\dagger}$ Department of Geography, National University \\ of Singapore, Singapore
}

(Received February 2006; accepted August 2006)

\begin{abstract}
This paper examines the innovation strategies driving Asian firms' investment in the US based on the resource-based model of knowledge. Specifically, it is shown that Asian firms' competitive advantage revolves around their ability to capture rents through a series of technological and marketing capabilities that collectively constitute the firms' knowledge resource base. The process of learning is documented by shedding light on the major sources of knowledge acquisition that enhance technological capabilities internally and externally. Specifically, this empirical research, based on a large-scale quantitative survey of Taiwanese, South Korean, and Singaporean firms in the US that was conducted between 2003 and 2004, shows that the firms in industrializing Asian economies (henceforth the IAFs) are directly investing in the US and setting up $R \& D$ operations there to acquire knowledge that enables them to become more innovative. A variety of technology sourcing strategies practiced among these IAFs was found, depending on their firm-specific variables (e.g. size and sector) and their prior technological capabilities. The types of technology and knowledge sources also go beyond conventional technological know-how to embrace the entire production chain from manufacturing technologies to expertise in marketing and distribution.
\end{abstract}

\section{Introduction}

A considerable body of research exists that attempts to explain the remarkable speed and level of technology development among firms from Asian newly industrialized economies (NIEs) (Hobday, 1995; Mathews \& Cho, 2000; Choung et al., 2000; Amsden, 2001; Mathews, 2002). Traditionally, firms in industrializing Asian economies (henceforth the IAFs) acquire technology through interactions with the foreign operations of transnational

Correspondence Address: Jinn-Yuh Hsu, Department of Geography, National Taiwan University, 1, Roosevelt Road, Section 4, Taipei 106, Taiwan. Fax: (886)2-23622911; Tel.: (886)2-23637260; Email: jinnyuh@ntu.edu.tw 
corporations (TNCs). They do so by exploiting technology and knowledge spillovers from inter-firm linkages that are established between foreign affiliates and domestic firms (Dunning \& Narula, 2004). However, with the emergence of "Third World" TNCs (see Yeung, 1999), particularly from South Korea, Taiwan, and Singapore recently, the IAFs are apparently becoming sources of technology generation, developing firm-specific technological capabilities as opposed to their more traditional role as importers of foreign technology from the US, Japan and Europe. To date, however, the literature has only begun to document the technological catch-up of the IAFs recently. Learning capacities of the IAFs are attributed to two major sources: namely, forward integration with more sophisticated markets in the US or Europe (Hobday, 1995), and technology and resource leverage through original equipment manufacturing (OEM) or through own design and manufacturing (ODM). As OEM suppliers, the IAFs secure contracting manufacturing jobs from TNCs or retail outlets in industrialized countries, although technology and market access are largely supplied by foreign contractors. As ODM suppliers, the IAFs are able to execute their own designs and technological capabilities (Mathews \& Cho, 2000).

This paper examines the innovation strategies driving Asian firms' investment in the US based on the resource-based model of knowledge. Specifically, it is shown that Asian firms' competitive advantage revolves around their ability to capture rents through a series of technological and marketing capabilities that collectively constitute the firms' knowledge resource base. The process of learning is documented by shedding light on the major sources of knowledge acquisition that enhance technological capabilities internally and externally. Specifically, this empirical research shows that the IAFs are directly investing in the US and setting up R\&D operations there to acquire knowledge that enables them to become more innovative. A variety of technology sourcing strategies practiced among these IAFs was found, depending on their firm-specific variables (e.g. size and sector) and their prior technological capabilities. The types of technology and knowledge sources also go beyond conventional technological know-how to embrace the entire production chain from manufacturing technologies to expertise in marketing and distribution. This empirical analysis is based on a large-scale quantitative survey of Taiwanese, South Korean, and Singaporean firms in the US that was conducted between 2003 and 2004. This dataset is supplemented by qualitative interviews with senior executives from parent companies in Taiwan, South Korea, and Singapore that offer unique insights into the specific mechanisms and complicated processes of knowledge transfers. These interviews originate from the longitudinal fieldwork involving personal on-site visits with various companies from the three economies between 2001 and 2004.

In the next section, trajectories of technological upgrading will be described to outline the different stages of technological development for East Asian latecomer firms. This section provides the organizational context for us to understand the recent direct acquisition of knowledge and expertise in the US by these leading Asian firms. In the third section, we explain in detail the various sources of knowledge acquisition in the US. The paper concludes with some implications of our findings for understanding and developing R\&D policies in the East Asian NIEs and, possibly, other developing countries.

\section{Trajectories of Technological Upgrading}

Trajectories of technological upgrading have become a critical issue for latecomer firms (see Amsden \& Chu, 2003). The product cycle model is commonly used to describe the 
pattern of development and production of a product during its entire lifespan in firms from advanced industrialized countries (Vernon, 1966; Utterback \& Abernathy, 1975). The model proposes that firms in these countries engage in $R \& D$ that results in new product innovations. Over time, product innovations give way to process innovations as the product moves through its life cycle. But it is doubtful if this theory is relevant for the IAFs from South Korea, Singapore, and Taiwan. In contrast to technologically advanced firms, latecomer firms from the Asian NIEs have adopted quite a different pathway of upgrading (Hobday, 1995; Shin, 1996; Kim, 1997; Kim \& Nelson, 2000; Hobday et al., 2004). They move backward from mature stages of the product cycle (process innovation) to early stages (product innovation) - a reversal of the product life cycle. For these firms, the future is somewhat path dependent in that they approach the technology frontier through the transfer of technology from firms in more advanced countries. In fact, Forbes and Wield (2000) have suggested that the innovative activities of the latecomer, as well as follower, firms manifest a number of features that are distinctive from those of the leaders in advanced industrialized countries. Latecomer innovation is characterized as incremental in nature, process-based, shop floor- situated, and design and development dominated, in contrast to leader innovation that is more radical in nature, product-based, laboratory-located, and R\&D-driven.

For developing countries, the effective acquisition of foreign technology has been an essential prerequisite for building their own technological capabilities that are taken as an important element in constituting their dynamic competitive advantage in the global economy (Ernst et al., 1998; Kim \& Nelson, 2000). However, technological learning is also complicated by several fundamental factors such as uncertainty, cumulativeness, embeddedness, and externalities. These factors make it difficult for technological learning to be analysed in standard economic models that assume rational and maximizing agents with a unique equilibrium state as the point of reference (Lall, 2000). The complex interaction of these factors also mean that trajectories of technological learning are mostly evolutionary and incremental as each new stage usually represents the (re)combination of technological capabilities between the previous stages and new added ones leveraged from external resources (Nelson \& Winter, 1982).

Three stages characterize East Asian firms' technological development. At the first stage, circa the 1960s, East Asian firms benefited from knowledge spillovers through forward and backward linkages that were forged with foreign TNCs. During this time, East Asian firms specialized in labour intensive industries and mainly targeted the domestic markets while technology transfer was largely realized through the movement of personnel and technical people on the one hand, and training of local suppliers on the other hand (Dicken, 2003). From the perspective of TNCs, foreign direct investment (FDI) was preferred than licensing and exports for the purpose of fully exploiting the rents of intangible assets, particularly their technologies and knowledge competence (Dunning, 1993). This mode of internationalization was particularly important if their intangible assets could in some measure be moved across national borders and could not be patented easily. As IAFs started industrializing and were not equipped with any significant technology, TNCs from industrialized countries were generally welcomed, at least among the Asian latercomers, to bridge the technology gap between the sending and receiving countries (Hobday, 1995; Kim, 1997; Dunning \& Narula, 2004).

The key issues involved are often the quality and degree of embeddedness of FDI in the host regions (Poon \& Thompson, 2003; Phelps et al., 2003; Hsu, 2004; Phelps \& Raines, 
2004). Different types of embeddedness are examined in terms of affiliate autonomy and local sourcing (Amin \& Thrift, 1994). ${ }^{1}$ Schive's (1990) 1973 survey of 311 exporting firms in Taiwan reveals that $86 \%$ of TNC subsidiaries applied the technology of their parent company in their production, and increased their local purchasing over eight times in the 1970s. ${ }^{2}$ And the most important vehicle through which foreign-owned firms disseminated technologies acquired from their home countries to Taiwan's domestic firms was labour mobility, i.e. worker movement from foreign-owned companies to Taiwanese firms. Former employees of foreign-owned firms are considered to have contributed greatly not only to domestic firms' improved technology and product design, but also to their managerial and marketing technology (Hou \& Gee, 1993, p. 389).

In the second stage in the late 1970s, some of the East Asian firms, particularly in Taiwan and South Korea, used OEM partnerships with global firms to acquire technology. Learning-by-doing was increasing supplemented with learning-by-interacting. ${ }^{3}$ Asian firms took advantage of their OEM positions to leverage technologies from key global buyers. Within the global commodity chain (GCC) literature, a common route of progressive upgrading is for producers that enter the chain to link up with their buyers and customers (Gereffi, 1999; Schmitz \& Knorringa, 2000; Humphrey \& Schmitz, 2002). Key global buyers help local producers in East Asia to improve technical and organizational skills to raise their product quality and production speed. An example of this is illustrated in the success of Taiwan's electronic producers in Figure 1 whose OEM relationship with leading US and Japanese companies helped stimulate knowledge creation, technology transfer, and improve domestic capabilities (Ernst, 2000; Borrus, 1997; Dedrick \& Kraemer, 1998). Many of these Taiwanese firms have since become significant ODM/ OBM (original brand manufacturing) players in the respective segments of the electronics industry today. In this OEM model, manufacturing activities are not only the driving force but also the economic precondition for technological investment and learning. In other words, manufacturing activities can generate and support the development of technological capacity. Learning-by-doing predominantly characterizes this phase of the manufacturing process, especially if needed technologies or skills are not in stock, but are still required to develop or produce the product. In these OEM arrangements, the latecomer firms "not only make an acceptable level of profit but also avoid the risk in developing the technology by themselves" (Hou \& Gee, 1993, p. 404).

However, the OEM model of technological learning met its limit by the late 1980s due to low entry barriers and the relative absence of research and design capabilities among these OEM firms. ${ }^{4}$ Meanwhile, the OEM makers were forced to upgrade their design and integration skills to serve their buyers better and more flexibly. In developing design and marketing competence, Asian firms faced obstacles because such upgrading encroached on their buyers' core competence. The model of ODM was introduced to describe the new role of the latecomer firms in East Asia. ${ }^{5}$ In this newer model, a global buyer first provides a local company a set of product ideas and/or concepts. The local company, in turn, designs the system, sources the components, and builds a product prototype according to these concepts from its buyers. The emergence of ODM represents a new international division of labour between the first-tier IAFs in Taiwan, South Korea, and Singapore, the second-tier ones in south-east Asia and China, and, the global buyers. Gereffi (1995) has proposed a role of "triangle manufacturing" for semi-peripheral manufacturers to move from direct suppliers for the US market to intermediaries in global production chains. The essence of triangle manufacturing is that the 


\begin{tabular}{|c|c|c|c|c|c|c|c|c|}
\hline $\begin{array}{c}\text { Brand name } \\
\text { manufacturers }\end{array}$ & Intel & Dell & IBM & Motorola & HPQ & Apple & NEC & Gateway \\
\hline IC & $\begin{array}{l}\text { TSMC } \\
\text { ASE } \\
\text { OSE }\end{array}$ & & TSMC & $\begin{array}{l}\text { TSMC } \\
\text { UMC } \\
\text { ASE }\end{array}$ & Macronix & & & \\
\hline PCB & $\begin{array}{c}\text { Compeq } \\
\text { Advtek } \\
\text { WUS }\end{array}$ & $\begin{array}{l}\text { Compeq } \\
\text { GCE } \\
\text { Unimicron }\end{array}$ & $\begin{array}{c}\text { Compeq } \\
\text { GCE } \\
\text { Advtek } \\
\text { Vertex } \\
\text { Precision }\end{array}$ & $\begin{array}{c}\text { WUS } \\
\text { Unitech } \\
\text { Yeti } \\
\text { Electronic } \\
\text { Unimicron } \\
\text { Qualitek }\end{array}$ & $\begin{array}{c}\text { Compeq } \\
\text { TPWC } \\
\text { GCE } \\
\text { Advtek } \\
\text { Vertex } \\
\text { Precision }\end{array}$ & WUS & & \\
\hline Desktop & & & Acer & & $\begin{array}{c}\text { FIC } \\
\text { Tatung } \\
\text { Mitac }\end{array}$ & & & \\
\hline Laptop & & $\begin{array}{l}\text { Wistron } \\
\text { Quanta } \\
\text { Compal }\end{array}$ & $\begin{array}{l}\text { Wistron } \\
\text { Quanta }\end{array}$ & & $\begin{array}{c}\text { Compal } \\
\text { Quanta } \\
\text { Arima } \\
\text { Inventec }\end{array}$ & $\begin{array}{c}\text { Quanta } \\
\text { Compal } \\
\text { ESC }\end{array}$ & $\begin{array}{c}\text { FIC } \\
\text { Quanta }\end{array}$ & Quanta \\
\hline Monitor & & $\begin{array}{l}\text { Liteon } \\
\text { BENQ }\end{array}$ & $\begin{array}{l}\text { Advtek } \\
\text { Tatung } \\
\text { BENQ }\end{array}$ & & Tatung & $\mathrm{ADi}$ & & MAG \\
\hline Power supply & DELTA & $\begin{array}{l}\text { DELTA } \\
\text { Liteon }\end{array}$ & $\begin{array}{l}\text { DELTA } \\
\text { Liteon }\end{array}$ & Liteon & DELTA & & Liteon & \\
\hline Case & & Foxconn & Foxconn & & $\begin{array}{c}\text { Foxconn } \\
\text { ENlight }\end{array}$ & & & \\
\hline $\begin{array}{c}\text { Power } \\
\text { connector }\end{array}$ & Foxconn & Foxconn & Foxconn & & Foxconn & Foxconn & & \\
\hline Main board & & & $\begin{array}{c}\text { Gigabyte } \\
\text { MSI } \\
\text { USI } \\
\end{array}$ & & & USI & $\begin{array}{c}\text { ECS } \\
\text { Gigabyte } \\
\text { MSI } \\
\end{array}$ & MSI \\
\hline Server & & & Quanta & & ASUS & & & \\
\hline Ethernet card & $\begin{array}{l}\text { Accton } \\
\text { D-LINK }\end{array}$ & & & & & & & \\
\hline Keyboard & & $\begin{array}{l}\text { Silitek } \\
\text { (Liteon } \\
\text { Group) } \\
\text { Chicony }\end{array}$ & Chicony & & $\begin{array}{l}\text { Silitek } \\
\text { (Liteon) } \\
\text { Chicony }\end{array}$ & $\begin{array}{l}\text { Silitek } \\
\text { (Liteon) } \\
\text { Chicony }\end{array}$ & & \\
\hline Scanner & & & & & $\begin{array}{l}\text { Avision } \\
\text { UMAX }\end{array}$ & & & \\
\hline
\end{tabular}

Figure 1. The relationship of global brand name manufacturers and OEM producers in Taiwan. Source: Wealth Magazine, 264, pp. 23-25, March 2004; and authors' interviews

first-tier Asian subcontractors and their located regions take the orders from their global buyers, and then shift part of the requested production to affiliated offshore factories in other peripheral Asian countries. In so doing, the intermediary manufacturers could upgrade their position in the global value chain.

Technological upgrading through learning-by-doing in the early 1980s was however somewhat passive. To be competitive in the late 1980s, a firm had to acquire aggressively as early as possible a firsthand knowledge of the products, and to design accordingly their own product models. This urgency also means a learning process that is different from learning-by-doing - a process of learning-for-doing (Lin, 2000). ${ }^{6}$ In other words, learning is not only a by-product of manufacturing, but also an activity of deliberate $\mathrm{R} \& \mathrm{D}$ that is 
increasingly engaged by the IAFs. Establishing R\&D divisions has become one of the major sources of competitive advantage for some IAFs across sectors. At the same time, it is widely acknowledged to be difficult to create and exploit technological capabilities by individual firms. A firm's competitiveness now depends not only on its own internal capabilities, but increasingly on the effectiveness with which it can gain access and utilize different sources of technological knowledge and capabilities beyond its firm-specific boundaries (Howells et al., 2003; Love, 2003). It is particularly true in technology-intensive industries where rapid technological change, growing technological complexity and shortening product life cycles prevail (Prahalad \& Hamel, 1990; Teece \& Pisano, 1994; Bannert \& Tschirky, 2004). Hence the early 1990s saw a number of the IAFs actively sourcing for foreign technologies through outward FDI to the US. This involved setting up research and design divisions, particularly in applied $R \& D$, in the US to acquire new knowledge processes and products (see also Chen (2004) for the case of China). At this stage, the OEM model is being complemented, rather than substituted, by an OBM model of technology development. Here the firm seeks to develop and sell its products under it own brand name rather than market its products under the brand names of its users and customers as is the case with OEM and ODM status. In Figure 2, these changing organizational relationships between Asian firms and their global buyers is illustrated. In particular, it is argued that Asian latecomers at different stages of technology development cater to different segments and tasks of global production networks and they consequently obtain the matching value-added embedded in these networks.

The transition to OBM, nevertheless, has not come easy for Asian latecomers. First, they have to build their own R\&D teams that tend to be costly, particularly for small and medium sized information technology (IT) firms. Second, competing with their contract buyers potentially hinders IAFs from building their own brands. ${ }^{7}$ To handle these issues, IAFs are beginning to source technologies both internally and externally to save $\mathrm{R} \& \mathrm{D}$ costs and to remain dynamically competitive. They are also targeting different products and market locations to avoid direct competition with their key buyers and to search for a complementary way to coexist with the latter (Hobday et al., 2004). Acer's focus on the Middle East and Eastern Europe, other than the conventional North American and Western European markets, is a case in point.

\section{Technological Learning and Upgrading in the US}

\section{US Sources of Learning: Quantitative Survey Evidence}

To examine the major sources of knowledge in the US that potentially contribute to IAF's learning and technological upgrading, we conducted a telephone survey of Taiwanese, South Korean and Singapore firms and their manufacturing FDI in the US between 2003 and 2004. The survey aims to test the hypothesis that marketing capability is positively related to Asian firms' innovation capability. Databases containing firm directories were obtained from Taipei's Economic and Cultural Office (New York), the Korean Chamber of Commerce and Industry, and Singapore's Science and Technology Board (now known as A*Star, Agency for Science, Technology and Research). Confirmation of the firms' investment activities in the US was supported through a web search of the companies and supplemented by telephone calls to companies whose activities were not hosted in any website. 


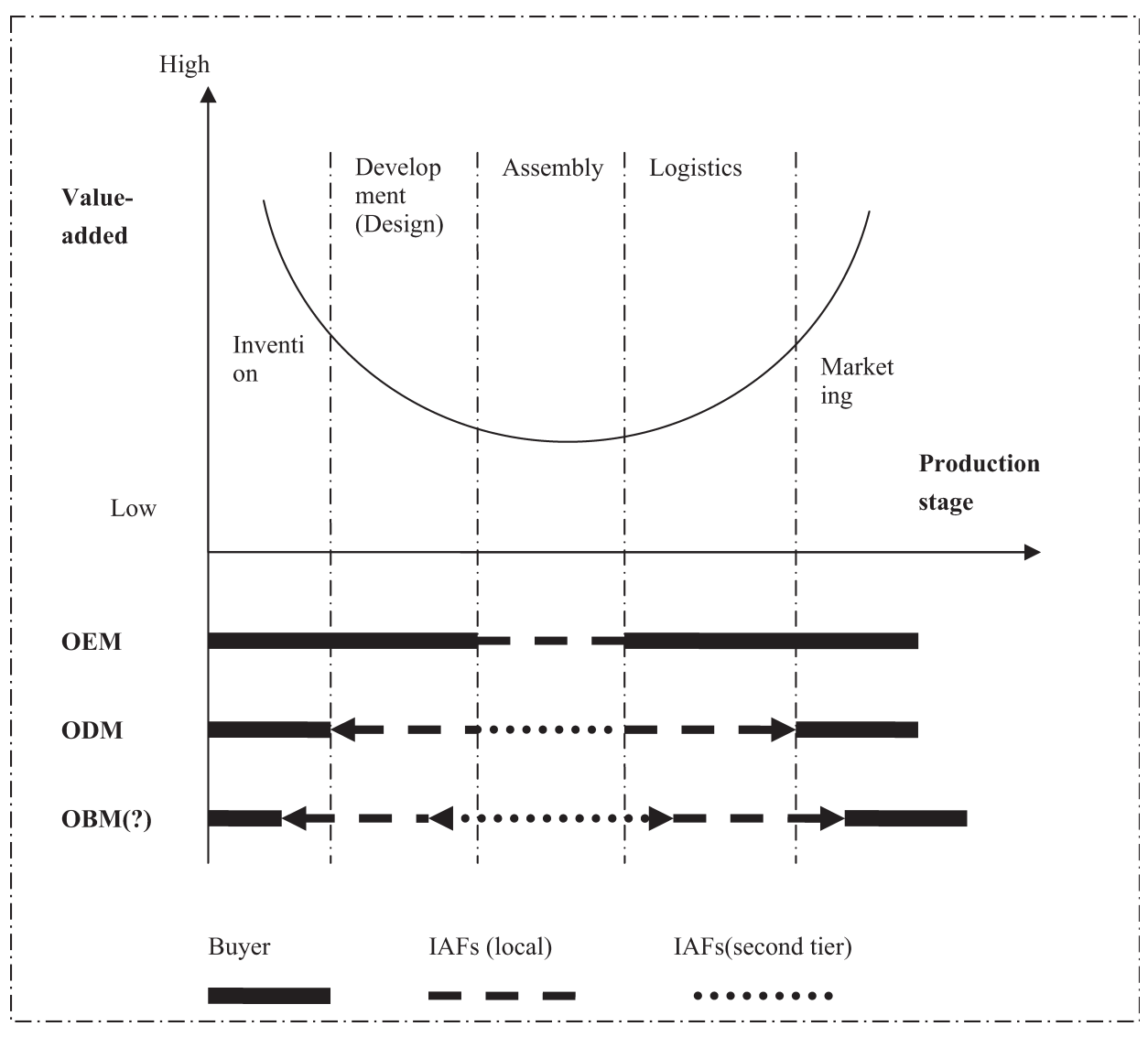

Figure 2. The combination of production and value chains of OEM, ODM and OBM

From company websites and telephone clarifications, we identified target populations for each of the three countries: 210 for Taiwan, 56 for Singapore, and 113 for South Korea. All 383 firms were contacted and a total of 151 responses were collected resulting in response rates of, respectively, 35\% (Taiwan), 44\% (South Korea), and 48\% (Singapore). Those who did not respond included individuals who refused to participate in the survey citing company policies, or, who were out of the country despite three or more attempts to contact them.

Our survey indicates important differences among the US subsidiaries of firms from these three Asian NIEs in terms of size and age: $95 \%$ of Taiwanese and $90 \%$ of Singaporean manufacturing firms tend to be small with world-wide sales of less than US\$250 million. In contrast, South Korean firms tend to be large with more than half reporting world-wide sales of over US $\$ 250$ million and at least a third over US\$1 billion. These findings are generally consistent with the industrial profile of the three economies. Outward FDI in the case of South Korean firms tends to be undertaken by large conglomerates known as chaebols (Shin, 1998; Sachwald, 2001), while larger Singaporean companies typically reflect the activities of government-linked corporations than small private companies (Yeung, 2002). Inward FDI to the US is also fairly recent among both Taiwanese and Singaporean firms 
with $75 \%$ of them directly investing in the US only in the last 10 years. However, $78 \%$ of Korean firms have been in the US for more than 10 years. In terms of sectoral distribution, computers, electronics and telecommunications account for more than $70 \%$ of the total FDI from these Asian NIEs in the manufacturing sector of the US.

Table 1 reports the results of an analysis of covariance that controls for sectoral differences on the sources of knowledge that are important to the IAFs' technological upgrading. Firms were asked to rank on a Likert scale of one to seven the importance of the various sources to their technological upgrading with one being very unimportant and seven being very important. The mean score results and $F$-statistics indicate interesting differences among the three Asian NIEs. Taiwanese firms appear to rely on multiple sources of knowledge transfers involving material transfer (reverse engineering, industrial certification), design transfer (trade shows) and capacity transfer (local relationships with customers, strategic alliance). Firms from South Korea and Singapore, however, rely much less on explicit knowledge forms that are associated with material and design transfers, and much more on customers, and in the case of Singapore, on strategic partners and technical consultants as well. What is clearly common to all three Asian NIEs are the high means scores given to local relationships with customers in the US. The $F$-statistics associated with industrial sectors also indicate that sectoral differences do not have an effect on the various sources of knowledge for the three countries. Indeed sectoral effect was further tested by applying ANCOVA to IAFs' principal industry and comparative advantage, that is electronics and computers. The results, which are not presented here, are virtually the same as those in Table 1 in terms of the significance of local relationships with customers among all three countries, the importance of reverse engineering and industry certification among Taiwanese firms, and, the importance of strategic alliances on both Singaporean and Taiwanese firms. Overall, Table 1 shows that relocation of facilities, particularly

Table 1. Analysis of covariance among different sources of learning in technological upgrading and knowledge acquisition in the US

\begin{tabular}{|c|c|c|c|c|c|}
\hline Sources & $\begin{array}{l}\text { Korea } \\
\text { (mean) }\end{array}$ & $\begin{array}{c}\text { Singapore } \\
\text { (mean) }\end{array}$ & $\begin{array}{l}\text { Taiwan } \\
\text { (mean) }\end{array}$ & $\begin{array}{c}\text { Country } \\
F \text {-statistics } \\
\text { ( } p \text {-value) }\end{array}$ & $\begin{array}{c}\text { Sector } \\
F \text {-statistics } \\
(p \text {-value })\end{array}$ \\
\hline $\begin{array}{l}\text { Technical } \\
\text { consultants }\end{array}$ & 1.9 & 4.4 & 3.6 & $15.49(0.000)^{* * *}$ & $2.26(0.135)$ \\
\hline $\begin{array}{l}\text { Industry trade } \\
\text { shows }\end{array}$ & 3.7 & 3.5 & 4.6 & $3.23(0.042)^{* *}$ & $0.26(0.611)$ \\
\hline $\begin{array}{l}\text { Blueprints/ } \\
\text { publications }\end{array}$ & 3.0 & 3.3 & 3.7 & $1.27(0.283)$ & $1.90(0.171)$ \\
\hline $\begin{array}{l}\text { Reverse } \\
\quad \text { engineering }\end{array}$ & 3.4 & 3.3 & 4.4 & $3.79(0.025)^{* *}$ & $0.65(0.421)$ \\
\hline $\begin{array}{l}\text { Industrial } \\
\text { certification }\end{array}$ & 2.2 & 3.7 & 4.5 & $14.54(0.000)^{* * *}$ & $0.99(0.322)$ \\
\hline Strategic alliance & 2.5 & 5.2 & 4.3 & $15.92(0.000)^{* * *}$ & $0.00(0.990)$ \\
\hline $\begin{array}{l}\text { Local relationships } \\
\text { with customers }\end{array}$ & 5.5 & 6.2 & 6.0 & $1.54(0.218)$ & $0.00(0.981)$ \\
\hline Seminars/training & 3.8 & 4.2 & 3.7 & $0.51(0.600)$ & \\
\hline
\end{tabular}

*** Significant at $1 \%$.

${ }^{* *}$ Significant at $5 \%$. 
$\mathrm{R} \& \mathrm{D}$ operations, to the US reflects a learning strategy that is becoming more relational or interaction-based. Interactions with customers are ranked equally highly at around six by firms from all three Asian NIEs and points to the rising significance of disembodied tacit technological knowledge in augmenting more explicit forms of knowledge acquisition. Indeed, South Korean and Singaporean firms did not rank codified knowledge forms highly as sources of technological upgrading.

To evaluate the effect of the technological sources and transfers on firms' technological capability in terms of knowledge and innovation rents, we perform an ordered probit regression that relates these sources to firms' introduction of new products since investing in the US. Ordered probit regression is used in this case because the dependent variable, new product introductions, is ordered from one to seven in increasing scale of importance. ${ }^{8}$ In addition to the sources of knowledge, three control variables were included, that is sector, age and firm size (world-wide sales) since earlier discussions suggest that the three Asian NIEs differ in these attributes. Table 2 reports the results. Technical/engineering consultants and industrial certification are found to be positive and marginally significant at the $10 \%$ level in firms' ability to introduce new products. Local relationships with customers emerge as the most positive and significant in contributing to firms' technological capability through new product introductions $(p=0.000)$. While not significant, the sign that is associated with the industrial sector variable is negative. This suggests that IAFs' dominant manufacturing industry, that is electronics and computers, is worthy of further investigation because this sector was coded with a lower numeric relative to other sectors like telecommunications. Hence the regression was re-run again for the electronics and computer

Table 2. Ordered probit regression analysis of the effect of knowledge sources on new product introductions

\begin{tabular}{lcc}
\hline Variable & $\begin{array}{c}\text { All sectors parameter } \\
\text { estimate }(p \text {-value })\end{array}$ & $\begin{array}{c}\text { Electronics/computers } \\
\text { parameter estimate }(p \text {-value })\end{array}$ \\
\hline Sector & $-0.008(0.659)$ & - \\
Age & $0.039(0.693)$ & $0.228(0.132)$ \\
Size & $0.0005(0.334)$ & $-0.000(0.417)$ \\
Technical consultants & $0.096(0.090)^{*}$ & $0.1289(0.072)^{*}$ \\
Industry trade shows & $0.016(0.778)$ & $-0.014(0.833)$ \\
Blueprints/publications & $-0.037(0.565)$ & $-0.038(0.623)$ \\
Reverse engineering & $0.005(0.929)$ & $-0.020(0.802)$ \\
Industrial certification & $0.095(0.073)^{*}$ & $0.107(0.124)$ \\
Strategic alliance & $-0.043(0.424)$ & $-0.040(0.589)$ \\
Local relationships with customers & $0.225(0.000)^{* * *}$ & $0.231(0.008)^{* * *}$ \\
Seminars/training & $0.832(0.192)$ & $0.044(0.577)$ \\
$\alpha_{2}$ & $-0.627(0.222)$ & $-0.877(0.182)$ \\
$\alpha_{3}$ & $-1.135(0.027)$ & $-1.192(0.070$ \\
$\alpha_{4}$ & $-1.351(0.009)$ & $-1.373(0.030)$ \\
$\alpha_{5}$ & $-1.873(0.004)$ & $-1.891(0.004)$ \\
$\alpha_{6}$ & $-2.609(0.000)$ & $-2.613(0.000)$ \\
$\alpha_{7}$ & $-3.275(0.000)$ & $-3.414(0.000)$ \\
Likelihood ratio $\left(\chi^{2}\right)$ & $36.64(0.000)^{* * *}$ & $19.88(0.03)^{* *}$ \\
\hline
\end{tabular}

*** Significant at $1 \%$.

** Significant at $5 \%$.

*Significant at $10 \%$. 
firms only and the results confirm that local relationships with customers are highly significant. In contrast, when separate ordered probit regressions were performed for other sectors, none of the knowledge sources in Table 2 was found to be significant. Overall Table 2 reveals that the significance of local customer relationships on new product introduction is largely driven by an industry (that is electronics and computers) that is known for its market and user-based innovations. Successful product development in this sector often flows from a detailed assessment of customer needs.

While the importance of customers may be explained in part by firms' OEM and ODM relationships with their US clients, it also reflects a strategy of external technological leveraging and upgrading - a shift to the acquisition of knowledge that encourages the development of OBM. Transition to OBM, however, requires not only the accumulation of capability that is technologically or scientifically-oriented. Innovation of this sort typically requires an additional non-technological dimension that is related to marketing and distribution capabilities, a point that we will return to in a later section. One of the oldest electronics companies in Taiwan, Tatung, for example became successful as an OEM and ODM supplier to American TNCs. However, it found the transition to OBM much more difficult because of serious marketing and distribution challenges. Its vice-president suggested that "Tatung" was linguistically unappealing as a brand name, hence marketing the product would require that the company considers changing and repackaging its brand name to a more culturally acceptable term in the US. However, this would hurt its reputation in Asia because Tatung is a household name in Asia, particularly in Taiwan (authors' interview, June 2004).

\section{Technological Learning and Transfer}

The earlier section suggests that the IAFs are turning to direct investment in the US to augment and supplement indigenous OEM and ODM strategies of technological learning and upgrading. This investment takes the form of establishing support facilities that include R\&D units in well-known US innovation areas such as Silicon Valley, North Carolina's Raleigh Research Triangle, and the New Jersey/New York City area. ${ }^{9}$ A major aim of this direct presence in the US is to develop new product capabilities through deploying R\&D personnel, and developing strong local relationships with customers. Firms also take advantage of geographical proximity and use R\&D labs as listening posts to monitor new developments in their major product lines (see Gertler (2003), Storper and Venerables (2004) and Boschma (2005) for a critical review of the relation between innovation and proximity). As these Asian firms grow older and become more embedded in the US, they have increasingly turned to the sourcing and internalization of more sophisticated knowledge forms, particularly that associated with tacit scientific knowledge that is much more difficult to transfer and acquire (Dougherty et al., 2000).

One of the major goals of learning and sourcing is to cultivate indigenous technological capabilities. ${ }^{10}$ To understand how knowledge is transferred and subsequently absorbed and transformed amongst the IAFs, we need to separate "material transfers" and "design transfers" from "capacity transfers" (Lall, 1987). Material transfer is characterized by the import of new materials and techniques and knowledge is typically built through reverse engineering or industrial certification processes. Local adaptation is not conducted in an orderly and systematic fashion. The local adaptation of borrowed technology and the development of new machines tend to occur primarily as a result of trial and error, i.e. 
"learning-by-doing". Design transfer is primarily carried out through the transfer of blueprints, formulae, publications or seminars. The knowledge contained in these design materials is predominantly coded and much more explicit, and must be adapted to local conditions. In addition, competitor products in an industry trade also constitute an important source of knowledge for design transfers. Capacity transfer refers to the transfer of scientific knowledge that leads to the production of locally adaptable technology, based on technology prototypes that exist abroad. A critical element in the process of capacity transfer is the mobility of scientists and engineers, as most of the innovative knowledge is human-embodied and diffuses through personal contact and association. Capacity transfer is therefore much more dependent on tacit knowledge forms. Sources of such knowledge may also come from external sources such as strategic alliance with another firm, or through the hiring of technical consultants. While technology transfer involves management and investment, it is difficult to rely exclusively on the transfer of machines and blueprints. Therefore, mobility of skilled personnel and external sources must be considered an essential element in the effective transfer of technology. In fact, among a number of ways for firms to tap into external technological knowledge and expertise, recruiting personnel directly from other companies or even competitors has been identified to be important (Kogut \& Zander, 1993; Koruna, 2004).

Recruiting experienced engineers and designers in the Silicon Valley is illustrated in the case of MXIC (Macronix International Co.), a firm that has tended to compete on product innovation, not cost reduction. Min Wu, the founder and Chief Executive Officer (CEO) who had previously worked for major US semiconductor firms, said that: "were it not for these adept engineers, MXIC would not have been able to stay on the right track. The upgrading of product levels could not have been possible without their inputs. To remain on the technology frontier, we had to recruit new engineers from Silicon Valley every year. I went to Silicon Valley to find the right people every year. They are like the roots of a tree, absorbing nutrients from outside. You've got the right people, you've got the right technology". ${ }^{11}$ By 2001, MXIC became the world's eighth largest supplier of the non-volatile memory. Besides luring skilled people back to Taiwan, MXIC also set up a technical development and marketing department in San Jose, California, as a listening post to tap into the powerhouse of integrated circuit (IC) product innovation. Through this department, MXIC subcontracted some product development jobs to overseas Taiwanese engineers. The department allowed those engineers who were reluctant to return to Taiwan to contribute their knowledge and experience to MXIC. The case of MXIC is not unique. High Tech Computer, a recent rising star in the smart phone design in which phones and other wireless gadgets perform many of the functions of a personal computer (PC), such as email checking and internet surfing, was managed by a team of three Taiwanese engineers who had worked in Digital Equipment Co. They developed a relationship with Microsoft and "learned the value of innovation", according to an industrial insider (Dean, 2004).

Of the three Asian NIEs, Taiwanese firms have been the most active in investing in overseas facilities to take charge of $R \& D$ and marketing in Silicon Valley. Some Taiwanese small chip design houses even establish Silicon Valley divisions to monitor the development of new technologies. As Mr C.-C. Huang, the president of Realtek, a small ASIC (application-specific IC) design house, argued: "Basically we recruit locally trained engineers that is sufficient to handle normal operations. If we want to maintain our place in the PC related market, however, we must also put a foot in Silicon Valley. This is why we decided to purchase Avance (a small Silicon Valley design house 
started by overseas Taiwanese engineers) as our division in Silicon Valley, the center of ASIC design. Through it, we are able to get access to first-hand marketing information, PC system development trends, and experienced talent in these areas". ${ }^{12}$ Howver, while Silicon Valley is also home to many South Koreans, a significant share (nearly half) may also be found in north-eastern US, particularly around the Boston/New York City conurbation. Clearly, skilled labour mobility through inter-firm transfers constitutes a relatively common technological solution for shortening the learning curve among the IAFs. However, this is often complemented by other sources of knowledge acquisition in the US.

\section{External Leveraging Strategies}

Effective technological learning requires absorptive capacity that contains two important elements: the existing knowledge base and the intensity of effort (Cohen \& Levinthal, 1990; Kim, 1997). Accumulated and existing knowledge increases the ability to make sense of, assimilate, and use new knowledge. The intensity of effort acts upon the dynamic learning strategies of the firms and refers to the amount of energy expended by firm members in new knowledge formation (Teece \& Pisano, 1994). As noted in the previous section, knowledge and innovation rent is quite significantly related to the IAFs' relationships with technical consultants in the US. Here, we might differentiate between two major types of leveraging strategies in technological upgrading. The first strategy of technical consultancy and patent licensing agreement is characterized by a low level of social interactions and commitment. Technology transfer occurs mainly through the market mechanism. In this type of technology outsourcing, once the agreement is signed, it requires little communication between the participating sides and the interactions are maintained by routine administration. In most cases, patent-licensing is chosen by firms that have already engaged in the development of the technology and that require the patent so that they can produce without fear of infringing upon the intellectual property rights of the patent holder. From the viewpoint of technology transfer, patent licensing by itself is not a useful strategy since most knowledge contained in the patent is codified and requires complementary channels, like personnel training, if the licensee is to assimilate the tacit part of a complete technology.

A higher level of social interactions tends to characterize the second strategy. Table 1 suggests that complementary technological assets that are acquired from strategic alliances are an important knowledge source for Taiwanese and Singaporean firms. Compared to other sources and channels of technology acquisition, some strategic partnership like joint development allows firms to stand on a more equal footing, since in most cases the parties to the agreement are involved under conditions of relatively similar levels of technological capability. Hence firms are better positioned to take advantage of the opportunities presented by collective learning. It is more effective than other, more markettransaction forms of technological acquisition (e.g. patent licensing), in allowing firms to exploit newly developed technologies because it encourages more intensive interaction between the members of participating firms. Knowledge embodied in personnel is critical for technology transfer in high-technology industries and the pooling of personnel in product development allows knowledge to be shared more directly. Joint development agreements allow firms to monitor the technological developments of competitors and 
appropriate tacit knowledge of new technologies. It is thus both a mechanism for absorption of information and knowledge, and, technological learning. To a large extent, collaborative alliances can be seen as "learning experiments" (Ciborra, 1992). As Robert Tsao, chairman of Taiwan's UMC (United Microelectronics Corporation) argued, "UMC collaborated with the semiconductor giants such as IBM and Infineon to develop new generation technologies in 2001. These joint development agreements with foreign companies provide us opportunities to observe what progress our competitors are making and, at the same time, keep track of new advances which we are incapable of developing on our own. Through our people, who work closely with our partners, we are able to obtain first-hand knowledge and then apply it to our own production". ${ }^{13}$ It is common for semiconductor manufacturers and design houses to set up R\&D labs in global technology hubs, particularly in Silicon Valley, to negotiate and engage in the development process with their partners (Mathews \& Cho, 2000).

Equity purchasing is another channel of technology transfer, particularly for those IAFs with huge capital accumulated from their previous OEM business. This involves high social interactions and commitment to ensure that the operation is smooth. Acquisition is usually used to tap directly into the core competence, particularly the brand design and market, of the targeted firm by the investing firm (Teece, 1986). ${ }^{14}$ However, it is one thing to acquire a stake in a firm, but quite another to transfer technology back to the parent company. Two conditions are at stake here. First, the success of the acquisition strategy hinges on the absorptive capacity of the investing firms because of knowledge tacitness and asset specificity in the technology transfer process. Some firms can do this relatively proficiently because they are building on a good base of in-house capability and sophistication, as Mowery and Oxley (1995) have shown in the case of Japanese IC companies.

Second, articulating and mobilizing the core competence of the acquired firm is the goal of most acquisitions, but there is typically a conflict between the management styles of the two firms involved in the alliance. Further, acquisition potentially leads to the loss of key personnel of the acquired firm, resulting in the investing firm gaining nothing but the physical assets. Such cases are not uncommon when the investing firms are relatively late entrants to the technology frontier and the acquired firms are relatively well established. One well known example is Acer Computer's acquisition of Counterpoint Computers Inc. in November 1987, and Altos Computers System in 1990. Stan Shih, the founder and Chairman of Acer, recalled the experience of acquiring Counterpoint and Altos as the highest price Acer ever paid for globalization: "These two companies were sold to Acer at a premium. That is, besides the net value, Acer also paid for goodwill and other intangible assets. Not only did we incur extra expenses, we also suffered from serious 'indigestion' due to the overall merger approach. Employees of the acquired companies were unable to adapt to the new corporate culture on a timely basis, and the deteriorating market condition also made them lose confidence, and they gradually left the company. At the end, Acer not only lost money but also lost the people". ${ }^{15}$

What this analysis suggests is that using strategic alliance for knowledge transfer is filled with challenges. However, this strategy tends to be pursued by smaller Singaporean and Taiwanese companies that are forced to pool resources because of their size. In the final section, we examine market and customer-oriented technological leveraging among the IAFs where the acquisition and deployment of innovation knowledge involves heavily non-technological forms, that is marketing and distribution. 


\section{Market-oriented Technological Upgrading}

Obtaining market information, developing distribution channels, and building brands among customers must complement the more technological dimensions of learning and upgrading for the IAFs that aim to become OBM. Barriers faced by the IAFs in the global markets are increasingly related to customer and marketing failures. Lacking control over marketing channels has been a major weakness among the IAFs to compete in more advanced markets. Two case studies, SIN from Singapore ${ }^{16}$ and Acer from Taiwan, illustrate this point.

SIN is a small IT firm that was founded by six Singaporeans. It originally built multifunction systems for small businesses or "Soho" (small office-home office systems). Small and home businesses typically cannot afford to purchase separate servers for their IT needs (e.g. print server, email server, file server, etc.) as it is rather costly. SIN's role is to provide low cost integrated systems that consolidate these servers for small businesses. US customers constitute almost all of the company's sales. However, with the purchase of its major US competitor Cobalt by SUN in the early 1990s, the Soho market declined as SUN's purchase virtually eliminated this market segment. This was complicated by the crash of dot.com in general in 2000. Since then, the company has realized that it has not been paying close attention to market trends and its relationship with its customers, and has embarked on an aggressive marketing of its products:

[SIN] today is very US driven. Before the Singapore company was calling the shots. Today we let the US office lead us. We conduct constant debates through teleconferencing. We visit the customer frequently-there is a quarterly review from customers. The partners go to the US every quarter. Our software engineers go there to support the product. The US R\&D team is a new addition. Previously, Singapore engineers were sent there for three months. They then returned to solve the problems of customers. This wasn't working ... We want to build products that the market wants. We didn't see ourselves going into security systems before. The US market led us to security systems. (authors' interview, December 2003)

Security system is a new product that has emerged out of the company's increased attention to customers' relationships and market needs. In this case, the company has begun building firewalls for their small business customers.

While SIN's case illustrates the IAFs' growing attention to the market and customers as a potential source of technological knowledge and capability, the transition to OBM is much more difficult. Taiwan's Acer has been pursuing its own brand name business since it was founded in 1976. At the beginning, it aggressively innovated by reverse engineering to catch market shares domestically and then internationally. To enter the US market, it engaged in acquisitions to gain access to local assets such as experienced engineers and distributive channels in the late 1980s, but failed nonetheless to make much headway. It tried to launch its Aspire computer in the US market again in 1995, but found it difficult to control local retail channels. As a result, the management soon found they had to keep a balance between OEM and OBM businesses, as the former had a faster cash turnover and low inventory cost, while the latter provided the company with value-added distribution (Shih, 1996). 
The continuing efforts of internationalization began to bear fruit in the early 2000s. A new opportunity for transition to OBM arose in the European market in the late 1990s. Acer acquired the laptop department of Texas Instrument (TI) in 1996 to use its brand for the product "Travelmate". Following this, the management and engineering team of TI's notebook computer department in Europe was merged into Acer Europe. Meanwhile, HP merged with Compaq in September 2001 to become the No.1 PC company in the world, and pushed a business model of direct sale. As a result, several of HP's established distributors joined Acer's European operation team. In contrast to the US market where the dealers played a critical role in sales, the European market was mainly controlled by distributors. Thus, acquisition has allowed Acer to gain access to the relevant marketing channels and experiences in the European context. However, to avoid repeating the previous failure of acquisition that resulted from the loss of experienced people in the acquired companies, Acer managers spent considerable amount of time negotiating with TI's leader, Gianfranco Lanci, and his team. To build up mutual trust, managers from both sides communicated by telephone every week, by videoconference each month, and by meeting in person every quarter (Shih, 2004). Stan Shih of Acer convinced Lanci that the TI team could take thorough control of Acer's operation in Europe, and would get full logistic support from Acer's headquarter in Taiwan.

Through intensive communication and negotiation, the merged entity did not lead to the loss of personnel, but instead enhanced Acer's competitiveness by adding local knowledge in marketing. Acer became the number one laptop in Europe, and Lanci was promoted to become the CEO at Acer's headquarter in 2004. This is the first time a major Taiwanesefounded company has promoted a non-Taiwanese marketing manager to the CEO position to handle the management and planning of a national champion. ${ }^{17}$ As argued by Stan Shih, "By promoting Lanci, an Italian marketing manager, to be the CEO, Acer aimed to emphasize its continuing efforts in pursuing its OBM and go-global strategy. Acquiring a good team would help lots and save us huge tuition in learning the foreign market ... But risk always existed in the A\&M investments, and we had to move carefully step by step. We were a small company, and could not keep people by money. Only through intensive negotiation and build up mutual trust, we could gain the cooperation from the targeted company and its running team. Gaining access to local knowledge through the channel of local marketing people is the short-cut to success in the new local market" (Shih, 2004).

To sum up, moving beyond low-cost manufacturing is vital for the IAFs, but current OEM/ODM practices are under constant pressure to shrink profit margins from more powerful PC buyers such as Dell and HP that usually play suppliers against each other to obtain the lowest price. An analysis by Merrill Lynch estimates that Taiwan ODM's gross profit margin for notebook PCs will slip to between $4 \%$ and $7 \%$ in 2005, from just over 6-9\% in 2003 (Dean, 2004). Under such circumstances, the OBM path is opted as a complementary strategy among firms to keep upgrading along global value chains. In contrast to the conventional practice where the IAFs' engineers mainly worked with foreign partners to configure components, the new strategy implies a more aggressive strategy in technological upgrading that increasingly focuses on marketing.

The transition from OEM/ODM to OBM strategies is not always smooth, as conflicts between the IAFs and their global buyers potentially lead to the loss of orders or even relationships with customers. For example, BenQ, formerly Acer Peripherals-a noted Taiwanese component supplier, began its own brand business after December 2001. In 2001, the Acer Group underwent another round of major reorganization that led to the 


\section{Jinn-Yuh Hsu et al.}

founding of four independent companies. Acer Peripherals was successfully spun off into an independent brand-name electronics and lifestyle manufacturer, BenQ. But BenQ soon found its OEM contract with Motorola diluted because BenQ had promoted its own cellular phones. Despite this, Kun-Yao Lee, its chairman and CEO, is determined to develop BenQ to become Taiwan's answer to Sony and Philips (authors' interview on 15 July 2004). The immediate challenge facing the IAFs' transition to OBM hinges on their abilities to target different products and market locations to avoid direct competition with their key buyers, and to search for a complementary way to coexist with the latter. The case of Acer's transition to OBM through the European market supports this point.

\section{Conclusion}

To develop firm-specific technology, a firm first needs to accumulate some basic technological know-how. East Asian firms attain this know-how capability initially by forging backward and forward linkages with the affiliates of foreign TNCs in Asia. The problem with relying on imported technology, however, is that the IAFs are unlikely to acquire more advanced forms of knowledge since the latter constitutes the principle ownership advantage of TNCs' operations abroad and they are notoriously tacit and difficult to be transferred beyond the firm's boundaires. Over time then, technological catch-up and narrowing involve firm strategies that enable the IAFs to acquire, build, and indigenize technologies through setting up R\&D operations in technology rich environments such as the US. As we have empirically shown in this paper, such a direct presence allows the IAFs not only to imitate and internalize technologies from leading US competitors and rivals, but also to engage directly in knowledge transfers with sophisticated buyers. In doing so, these IAFs can accumulate new stocks of technological competencies and eventually transfer them back to their Asian headquarters for further development into specific products.

As the IAFs increasingly use external relationships to acquire new knowledge, they need to develop the capability for acquiring know-how and know-why through external sources. The IAFs' technology sourcing in the US is associated with market-based product innovations where the market constitutes the most important source of learning for product development. Therefore, Asian firms have invested directly in their US facilities to source for the latest market knowledge. In addition, product innovations in the IAFs are not nearly as radical as their industrialized counterparts. Most of the innovations involve the improvement of existing products they supply as OEM and ODM subcontractors to their customers. This process is supplemented by new ideas leveraged from core and sophisticated markets such as the US. As the IAFs move further from ODM to OBM, they will need more external knowledge about markets and customers. In so doing, the IAFs move backward from mature stages of the product life cycle to early stages of product innovations, thereby chartering a reversed path of the product life cycle (Hobday, 1995; Kim, 1997). This finding tends to contradict the standard product life cycle hypothesis.

We found an interesting variety of technological leveraging methods that involve different degrees of social interaction with the IAFs' external environment. Effective technology transfer involves the movement of personnel, and, the establishment of marketing channels, and close customer relationships in the US because such knowledge is often tacit and embodied. These strategies are complemented by other knowledge sources 
including technical consultants and strategic alliances with companies in the US. Together, these strategies may well enable the IAFs to move from OEM to ODM and OBM in the global division of labour. However, it also impinges on the IAFs to invest in in-house $R \& D$ that help realize absorptive capabilities, even though this might have the effect of direct competition with their buyers. Nonetheless, actively searching for complementary technology and knowledge in more sophisticated markets such as the US should move the IAFs away from their hitherto heavy reliance on subcontracting relationships as the major source of technological growth in favour of more independent and indigenous technological accumulation-an emerging pathway of firm-specific development that mirrors very much the national R\&D policy of many East Asian newly industrialized economies.

\section{Acknowledgements}

This is a revised version of a paper presented earlier at the Annual Meeting of the Association of American Geographers, Denver, USA, 5-9 April 2005. The authors are grateful to the discussant, Dr Susan Walcott, and the participants for their helpful comments. In addition, the authors wish to thank two referees for their constructive comments which led to significant improvement of the paper. The authors would also like to thank the following funding agencies for supporting the research on which this paper is based: the National Science Council in Taiwan (NSC 92-2415-H-002-020-SSS), the Programme for Globalization Studies of the Institute for Advanced Studies in Humanities and Social Sciences at the National Taiwan University, the National Science Foundation (award no: BCS-0137045) and the National University of Singapore Academic Research Fund (R-109-000-050-112). The authors take responsibility for all errors and/or mistakes.

\section{Notes}

1. Poon and Thompson (2003) explore the relationship between the embeddedness of technology-oriented functions among different types of foreign subsidiaries in Asian cities, and make a distinction between developmental subsidiary, which actively exploits location-specific advantages and pursues R\&D activities in host locations, and quiescent subsidiary, which rarely develops new products and less than often engages in R\&D activities in host localities. Their study shows that different types of foreign subsidiaries create divergent types of technological linkages to developing countries. For a similar empirical study, see Ivarsson and Alvstam (2004) on technology transfer in India through the investment of Sweden's Volvo.

2. However, foreign companies that are located in export processing zones purchased less than those outside, and thus transferred less technology to local suppliers (Schive, 1990).

3. The different stages do not necessarily describe all Asian countries. As demonstrated by Hobday (2002), while the OEM system dominates Taiwanese and Korean firms, TNC-led growth is more important in Singapore and Malaysia. Nevertheless, all of these three stages in various sequences represent the major technology strategies adopted by latecomer firms to compete in the global economy.

4. Ernst (2002) shows that overwhelming reliance on OEM renders South Korean PC companies incapable of launching their own brand name products in direct competition to the world market leaders.

5. The design part in the ODM model is defined as the deliberate conceptualization of a product to achieve certain desirable performance characteristics (Forbes \& Wield, 2000). More importantly, the design prototype and functional requirement are mainly designated by the key buyers, rather than by the ODM makers.

6. As observed by Lin (2000), in a mode of learning by doing, a producer does not design the product and may not bear the related technological knowledge and skills before undertaking the production. In a 


\section{Jinn-Yuh Hsu et al.}

mode of learning for doing, however, a producer will be the designer of a product or the so-called fast follower. It therefore has to acquire to a certain degree the related technologies and skills even before the phase of product design. From the late 1980s onward, formal and specific R\&D units and design teams were gradually organized among leading Asian firms.

7. Hobday et al. (2004) have posed this issue as an innovation dilemma. Hobday questions if the latecomer firms should compete as R\&D and brand leaders in the international stage or if they should continue with their tried and tested formula of low cost catch up to enhance competitiveness.

8. More specifically, an ordered probit regression may be expressed as: $y_{i}{ }^{*}=\mathbf{x}_{\mathbf{i}} \boldsymbol{\beta}_{\mathbf{i}}+\epsilon_{i}$ where $\mathbf{x}_{\mathbf{i}}$ is a vector of explanatory variables, $\boldsymbol{\beta}_{\mathbf{i}}$ is a column vector of parameters to be estimated with the first element being the intercept, $y_{i}{ }^{*}$ is the latent variable and $\epsilon_{i}$ is the random error term which is assumed to follow a normal distribution. The ordered probit model is derived from a measurement model where the latent variable, which ranges from $-\infty$ to $\infty$, is mapped to an observable variable $y$ such that the extreme interval categories $\varphi_{0}=-\infty$ and $\varphi_{j}=\infty$.

9. For example, a sample of Taiwanese companies that have R\&D activities in the US include Multitech (Acer), Plus \& Plus (America Research Corporation), Mitac, Tatung, and Advanced Data (see Liu, 1987).

10. According to Bell and Pavitt (1993, p. 163), technological capabilities consist of the resources needed to generate and manage technical change, including skills, knowledge and experience, and institutional structures and linkages.

11. Authors' interview with Min Wu, 26 September 2001 and 9 July 2004.

12. Authors' interview with C.-C. Huang, 21 September 2004.

13. Authors' interview with Rober Tsao, 25 November 2001.

14. Bobo Wang, President of Microtek, commented on his company's participation in the acquisition of Mouse Systems: "This deal provides a good example of how local manufacturers can enter the international market by acquiring worthwhile foreign companies, technologies and sales channels. Our strategy is to produce, through acquisition, products which can rank Microtek among the top three in those specific fields worldwide, and thus guarantee competitiveness and profitability" (quoted in Peng, 1990, p. 16).

15. Authors' interview with Stan Shih, 16 June 2002.

16. The Singaporean company is given a fictitious name to protect its anonymity. All information presented is based on authors' interviews in the US and Singapore.

17. An interesting comparison is Sony's recent decision to promote the president of its US operation to Sony's CEO in March 2005.

\section{References}

Amin, A. \& Thrift, N. (Eds) (1994) Globalization, Institutions and Regional Development in Europe (Oxford: Oxford University Press).

Amsden, A. H. (2001) The Rise of "The Rest": Challenges to the West From Late-Industrializing Economies (New York: Oxford University Press).

Amsden, A. H. \& Chu, W. W. (2003) Beyond Late Development: Taiwan's Upgrading Policies (Cambridge, MA: MIT Press).

Bannert, V. \& Tschirky, H. (2004) Integration planning for technology intensive acquisitions, R\&D Management, 34(5), pp. 481-494.

Bell, M. \& Pavitt, K. (1993) Technological accumulation and industrial growth: Contrasts between developed and developing countries, Industrial and Corporate Change, 2(2), pp. 157-210.

Borrus, M. (1997) Left for dead: Asian production networks and the revival of US electronics, in: B. Naughton (Ed.) The China Circle (Washington, DC: Brookings).

Boschma, R. (2005) Proximity and innovation: A critical assessment, Regional Studies, 39(1), pp. 61-74.

Chen, S. H. (2004) Taiwanese IT firms' offshore R\&D in China and the connection with the global innovation network, Research Policy, 33, pp. 337-349.

Choung, J., Hwang, H. \& Rim, M. (2000) Transition of latecomer firms from technology users to technology generators: Korean semiconductor firms, World Development, 28(5), pp. 969-982.

Ciborra, C. (1992) Innovation, networks and organizational learning, in: C. Antonelli (Ed.) The Economics of Information Networks (New York: North-Holland). 
Cohen, W. \& Levinthal, D. (1990) Absorptive capacity: A new perspective on learning and innovation, Administrative Science Quarterly, 35, pp. 128-152.

Dean, J. (2004) Taiwan tech's snazzy new look, Far Eastern Economic Review, 167(35), pp. 28-31.

Dedrick, J. \& Kraemer, K. (1998) Asia's Computer Challenge (New York: Oxford University Press).

Dicken, P. (2003) Global Shift: Reshaping the Global Economic Map in the 21st Century (New York: The Guilford Press).

Dougherty, D., Borrelli, L., Munir, K. \& O' Sullivan, A. (2000) Systems of organizational sensemaking for sustained product innovation, Journal of Engineering and Technology Management, 17(3/4), pp. 321-355.

Dunning, J. H. (1993) Multinational Enterprises and the Global Economy (Reading, MA: Addison-Wesley).

Dunning, J. H. \& Narula, R. (2004) Multinationals and Industrial Competitiveness: A New Agenda (Cheltenham: Edward Elgar).

Ernst, D. (2000) What permits David to grow in the shadow of Goliath? The Taiwanese model in the computer industry, in: M. Borrus, D. Ernst \& S. Haggard (Eds) International Production Networks in Asia. Rivalry or Riches? (London: Routledge).

Ernst, D. (2002) Global production networks and the changing geography of innovation systems. Implications for developing countries, Journal of the Economics of Innovation and New Technologies, 11(6), pp. 497-523.

Ernst, D., Ganiatsos, T. \& Mytelka, L. (Eds) (1998) Technological Capabilities and Export Success in Asia (London: Routledge).

Forbes, N. \& Wield, D. (2000) Managing R\&D in technology—followers, Research Policy, 29(9), pp. 10951109.

Gereffi, G. (1995) Global production systems and third world development, in: B. Stallings (Ed.) Global Change, Regional Response (Cambridge: Cambridge University Press).

Gereffi, G. (1999) International trade and industrial upgrading in the apparel commodity chain, Journal of International Economics, 48, pp. 37-70.

Gertler, M. (2003) Tacit knowledge and the economic geography of context, or the undefinable tacitness of being (there), Journal of economic Geography, 3(1), pp. 75-99.

Hobday, M. (1995) East Asian latecomer firms: learning the technology of electronics, World Development, 23(7), pp. $1171-1193$.

Hobday, M. (2002) Innovation in Asian industrialization: A Gerschenkronian perspective, Oxford Development Studies, 31(3), pp. 293-314.

Hobday, M., Rush, H. \& Bessant, J. (2004) Approaching the innovation frontier in Korea: The transition phase to leadership, Research Policy, 33(10), pp. 1433-1457.

Hou, C. \& Gee, S. (1993) National systems supporting technical advance in industry: The case of Taiwan, in: R. Nelson (Ed.) National Innovation Systems: A Comparative Analysis (Oxford: Oxford University Press).

Howells, J., James, A. \& Malik, K. (2003) The sourcing of technological knowledge: distributed innovation processes and dynamic change, $R \& D$ Management, 33(4), pp. 395-409.

Hsu, Jinn-yuh (2004) The evolving institutional embeddedness of a late-industrial District in Taiwan, Tijdschrift voor Economische en Sociale Geografie, 95(2), pp. 218-232.

Humphrey, J. \& Schmitz, H. (2002) How does insertion in global value chains affect upgrading in industrial clusters?, Regional Studies, 36(9), pp. 1017-1027.

Ivarsson, I. \& Alvstam, C. (2004) International technology transfer through local business linkages: The case of Volvo trucks and their domestic suppliers in India, Oxford Development Studies, 32(2), pp. 241-260.

Kim, L. (1997) Imitation to Innovation: The Dynamics of Korea's Technological Learning (Boston, MA: Harvard Business School Press).

Kim, L. \& Nelson, R. (Eds) (2000) Technology, Learning and Innovation (Cambridge: Cambridge University Press).

Kogut, B. \& Zander, I. (1993) Knowledge of the firm and the evolutionary theory of the multinational corporation, Journal of International Business Studies, 24(4), 625-645.

Koruna, S. (2004) Leveraging knowledge assets: Combinative capabilities-theory and practice, R\&D Management, 34(5), pp. 505-516.

Lall, S. (1987) Learning to Industrialize: The Acquisition of Technological Capability by India (London: Macmillan).

Lall, S. (2000) Technological change and industrialization in the Asian newly industrializing economies: Achievements and challenges, in: L. Kim \& R. Nelson (Eds) Technology, Learning and Innovation (Cambridge: Cambridge University Press).

Lin, T. (2000) The social and economic origins of technological capacity: A case study of the Taiwanese computer industry, PhD Dissertation, Department of Sociology, The Temple University, Philadelphia, PA. 


\section{Jinn-Yuh Hsu et al.}

Liu, P. (1987) Taiwanese electronics firms set up U.S. investment, Electronic Business, March, pp. 30-32.

Love, J. (2003) Technology sourcing versus technology exploitation: An analysis of US foreign direct investment flows, Applied Economics, 35, pp. 1667-1678.

Mathews, J. A. (2002) Dragon Multinational: A New Model for Global Growth (Oxford: Oxford University Press).

Mathews, J. A. \& Cho, D. S. (2000) Tiger Technology: The Creation of a Semiconductor Industry in East Asia (Cambridge: Cambridge University Press).

Mowery, D. \& Oxley, J. (1995) Inward technology transfer and competitiveness: The role of national innovation systems, Cambridge Journal of Economics, 19, pp. 67-93.

Nelson, R. R. \& Winter, S. G. (1982) An Evolutionary Theory of Economic Change (Cambridge, MA: Harvard University Press).

Peng, P. (1990) Innovation is my life-says Bill Gates, Information and Computer, January, pp. 14-19.

Phelps, N. \& Raines, P. (Eds) (2004) The New Competition for Inward Investment: Companies, Institutions and Territorial Development (Cheltenham: Edward Elgar).

Phelps, N., Mackinnon, D., Stone, I. \& Braidford, P. (2003) Embedding the multinationals? Institutions and the development of overseas manufacturing affiliates in Wales and north east England, Regional Studies, 37(1), pp. $27-40$.

Poon, J. \& Thompson, E. (2003) Developmental and quiescent subsidiaries in the Asia Pacific: Evidence from Hong Kong, Singapore, Shanghai, and Sydney, Economic Geography, 79(2), pp. 195-214.

Prahalad, C. \& Hamel, G. (1990) The core competence of the corporation, Harvard Business Review, May-June, pp. 79-91.

Sachwald, F. (Ed.) (2001) Going Multinational: The Korean Experience of Direct Investment (London: Routledge).

Schive, C. (1990) The Foreign Factor: The Multinational Corporation's Contribution to the Economic Modernization of the Republic of China (Stanford, CA: Hoover Institution Press).

Schmitz, H. \& Knorringa, P. (2000) Learning from global buyers, Journal of Development Studies, 37(2), pp. $177-205$.

Shih, S. (1996) Reengineering Acer (Taipei: Commonwealth Publishing Co.) (in Chinese).

Shih, S. (2004) The Epochal Change of Acer: Fading Out Manufacturing and Reaching Out Brand-name Making (Taipei: Commonwealth Publishing Co.) (in Chinese).

Shin, J. S. (1996) The Economics of the Latecomers: Catching-up, Technology Transfer and Institutions in Germany, Japan and South Korea (London: Routledge).

Shin, Y. S. (1998) European Integration and Foreign Direct Investment in the EU: The Case of the Korean Consumer Electronics Industry (London: Routledge).

Storper, M. \& Venables, A. (2004) Buzz: Face-to-face contact and urban economy, Journal of Economic Geography, 4(4), pp. 351-370.

Teece, D. (1986) Profiting from technological innovation: Implications for integration, collaboration, licensing, and public policy, Research Policy, 15, 286-305.

Teece, D. \& Pisano, G. (1994) The dynamic capabilities of firms: An introduction, Industrial and Corporate Change, 3(3), pp. 537-556.

Utterback, J. \& Abernathy, W. (1975) A dynamic model of process and product innovation, Omega, 3, pp. 639-656.

Vernon, R. (1966) International investment and international trade in the product cycle, Quarterly Journal of Economics, 80, pp. 190-207.

Yeung, H. W. C. (Ed.) (1999) The Globalisation of Business Firms from Emerging Economies (Cheltenham: Edward Elgar).

Yeung, H. W. C. (2002) Entrepreneurship and the Internationalisation of Asian Firms: An Institutional Perspective (Cheltenham: Edward Elgar). 
Copyright of European Planning Studies is the property of Routledge and its content may not be copied or emailed to multiple sites or posted to a listserv without the copyright holder's express written permission. However, users may print, download, or email articles for individual use. 